\title{
SOME ASPECTS OF LOCAL REAL ESTATE TAXES AS AN INSTRUMENT OF LAND USE MANAGEMENT
}

\author{
Sabina Źróbek, prof. \\ Faculty of Geodesy, Geospatial and Civil Engineering \\ University of Warmia and Mazury in Olsztyn, Poland \\ e-mail:zrobek@uwm.edu.pl
}

Siarhei Manzhynski, prof.

Department of Economics and Plant Managemen

Belarusian State Technological University, Minsk, Belarus

Elżbieta Zysk, Ph.D.

Faculty of Geodesy, Geospatial and Civil Engineering

University of Warmia and Mazury in Olsztyn, Poland

e-mail: elzbieta.zysk@uwm.edu.pl

Yauheni Rassokha, prof.

Department of Production Organization and Real Estate Economics

Belarusian State Technological University, Minsk, Belarus

\begin{abstract}
Economic and financial instruments are a very important group of tools for supporting local entrepreneurship. The broadest group among them are local taxes. Real estate taxes are considered by local governments, on the one hand, as a tool for promoting the effective development of real estate, and on the other, as a reliable source of income to the local budget.

The functioning of every tax system can be analyzed by applying different criteria. The most typically evaluated criteria are: economic efficiency, equity, transparency, collectability and revenue production. These criteria are often in conflict with one another, one of the reasons for this fact being, according to the research conducted by the authors of this paper, the base of taxation. It is generally believed that the value of real property is a much more reliable tax basis than its size.

It was our intention to verify this opinion. Having reviewed the available literature and thoroughly analyzed the Polish and Belarussian real estate tax systems, we concluded that the first of the two systems has no definite advantages over the other. For example, the ad valorem tax better stimulates intensive use of land, but, on the other hand, may negatively affect its sustainable development. The main reason for this fact is the specificity of real estate as the object of taxation. The object of taxation exists regardless of its economic state and performance, thus taxes have to be paid whether or not there is any income or profit. Given the nature and possible functions of real estate and the priorities of local authorities, the concept of just taxation is also socially relative.
\end{abstract}

Key words: real estate, local taxes, community budget, market value, land use management.

JEL Classification: K34, O21, R00, R28

Citation: Źróbek S., Manzhynski S., Zysk E., RassokhaY., 2016, Some Aspects of Local Real Estate Taxes as An Instrument of Land Use Management, Real Estate Management and Valuation, Vol. 24, No. 3, pp. 93105.

DOI: $10.1515 /$ remav-2016-0024 


\section{Introduction}

According to T. Burns and K. Darlymple, the essence of land administration typically involves processes that: manage public land, record and register private interests in land, assess land value, determine property tax obligations, define land use and management governance systems, and support the development, application and approval process for land use (BURNS, DARLYMPLE 2008). This means that real estate management and administration are complex processes. Other authors also include, in these processes, such elements as: initiating and supervising land development processes, land use protection, deriving income from sale, lease and taxes, as well as settling disputes regarding the rights to real estate and the principles of their use (DALE, MCLAUGHLIN 1999). The tools used by local authorities to support local business include, among others: legal tools, investment tools (technical and environmental protection infrastructures), organizational tools (streamlining cooperation between various organizations) and information tools (activities associated with information and promotion). The instruments used by local governments to raise revenue can have an impact on the nature, location, and density of development. Local governments can affect urban form, not only with planning tools, but also with municipal financial tools (BIRD, SLACK 2002, HUNKER et al. 2015).

Economic and financial instruments are a very important group of tools for supporting local entrepreneurship. The broadest group among is constituted by local taxes.

In some cases, municipal financial tools work together with planning tools, but in other cases, they may have the opposite effect (BIRD, SLACK 2002). The tax that influences the development of entrepreneurship most, and thus also has an indirect impact on living conditions in specific areas (communes), is the real estate tax (SADOWSKA-SPYCHAŁA 2013). According to Youngman and Reschowsky (2007), real estate tax is the fairest, most transparent and most reliable of all the mechanisms of increasing income in a commune. Groover said that high tax rates (despite their increase being justified by needs) also hinder the inflow of investors to a commune. By giving special property tax relief, in some cases, a local government has the possibility to encourage one type of land use over another, or attract new investment to the area (GROVER et al. 2015).

Unfortunately, the research conducted in Poland suggests that the most typical measure used by communes to encourage investment through real estate tax policy is tax rate reduction. It should be noted that real estate is a specific kind of merchandise that is not traded as commonly as other merchandise, e.g. consumer goods (FLIS 2015). The durability of real estate stimulates its long use (perpetual usufruct in the case of land). This is one of the reasons why, in order to determine various taxes and charges associated with the use and disposal of real estate, a special system for determining the base of taxation is required. Globally, two basic systems function to determine the amount of tax, i.e.: 1. as the product of the value of real estate and the tax rate, and 2. as the product of the size of the object of taxation and tax rate. In some countries, the value of buildings and structures as the object of taxation used to be related to the costs of their construction. Now, most countries use market value, both for land and for attached structures (TROJANEK 2015, GROVER et al. 2015, ALMY 2001, ŠUBICKOVAĆ 2015, BARAŃSKA 2013). It is often referred to as cadastral value, tax value or fiscal value. In the other system, the amount of tax is determined by the size of a parcel, the usable surface of a building or premises, and the tax rate determined annually by the local government (КОКОт 2009, GEUSZAK, MARONA 2015, WALACIK 2015). The most important elements of the real estate tax system are: the object of taxation, the tax payer, the base of taxation, tax rates and tax exemptions.

On the other hand, how every tax system functions in practice can be described and analyzed by applying different criteria. The most typically evaluated elements are: economic efficiency, equity, transparency, collectability and revenue production. These criteria are often in conflict with one another, which forces politicians to make compromises (Ross 2014, Institute on Taxation and Economic Policy, 2011). Our hypothesis is that the general opinion that charging real estate tax on the basis of the value of real estate is the more efficient and just of the two systems is not well substantiated. To prove the hypothesis, we analyzed substantial literature in the area. We also performed an in-depth analysis of Polish and Belarusian taxes. These two countries, although neighbors, have different political and economic systems. Poland is a parliamentary republic with a market economy, whereas Belarus has a semi-presidential political system and a centrally controlled economy. Real estate in both countries is subject to taxation. In both countries, taxes are paid to the local budget. However, there are some differences in specific principles of taxing land, buildings, structures and premises. Also, the two 
countries have different priorities for streamlining the tax system. The two systems were analyzed mainly from the perspective of the legal framework for, and the base and rate of, taxation. It is generally believed that the value of real property is an economically more effective and more just base of taxation than its size. It was our intention to verify this opinion by:

1) presenting the Polish and Belarusian systems of real estate taxation,

2) discussing the strengths and weaknesses of the size and value of real estate, respectively, as the base of taxation.

\section{General information about Poland and Belarus}

There is a tripartite administrative division in Poland into: voivodships, poviats and gminas (provinces, counties and communes). These areas contain cities, towns and villages. Belarus consists of regions divided into districts, plus the city of Minsk, which is the country's capital. Selected data concerning the two countries have been presented in Table No. 1.

Table 1

Poland and Belarus - general information

\begin{tabular}{|c|c|}
\hline Poland & Belarus \\
\hline \multicolumn{2}{|c|}{ Population } \\
\hline $38.53 \mathrm{mln}$ & $9.50 \mathrm{mln}$ \\
\hline \multicolumn{2}{|c|}{ Geodesical area in ha } \\
\hline $\begin{array}{c}31,267,938 \text { ha }(100 \%) \text { in which urbanized areas } \\
\text { represent } 1,529,364 \text { ha in total }(4.89 \%) \text { in which: } \\
\text { - urban areas: } 1.82 \%, \\
\text { - rural areas: } 3.07 \% .\end{array}$ & $\begin{array}{c}20,760,000 \text { ha }(100 \%) \text { in which urbanized areas } \\
\text { represent 271,956 ha in total }(1.31 \%) \text { in which: } \\
\text { - urban areas: } 1.51 \%, \\
\text { - rural areas: } 2.78 \% .\end{array}$ \\
\hline
\end{tabular}

\begin{tabular}{cc}
\hline & Administrative structure \\
\hline provinces - 16 & provinces - 6 + Minsk as a dedicated city \\
\hline counties - 378 & counties -118 + 10 cities on the law as counties \\
\hline communes - 2,478 & communes - 1308 \\
of which: & in cities: \\
city communes - 306 & city executive committees - 149 \\
rural communes - 1570 & in rural areas: \\
urban-rural communes - 602 & rural executive committees - 1159
\end{tabular}

Type of real estate ownership

\begin{tabular}{|c|c|}
\hline private ownership $-58 \%$ & private ownership $-45.8 \%$ \\
\hline $\begin{array}{l}\text { state ownership (properties of State Treasury, } \\
\text { properties of the state owned by legal entities, } \\
\text { state - owned agricultural resources) - } 38 \%\end{array}$ & state ownership - 50.7\% \\
\hline $\begin{array}{c}\text { local government ownership (voivodships, } \\
\text { counties, communes) }-4 \%\end{array}$ & no data \\
\hline No data & foreign ownership $-3.5 \%$ \\
\hline \multicolumn{2}{|c|}{ Data from register of land and buildings } \\
\hline $\begin{array}{l}\text { The whole area of Poland is included in the } \\
\text { Land and Building Cadaster which consists of: } \\
\text {-land real estate (with or without buildings) - } \\
\qquad 33 \text { mln parcels }\end{array}$ & $\begin{array}{l}\text { The whole area of Belarus is included in the } \\
\text { Land and Building Cadaster which consists of: } \\
\text {-land real estate (with or without buildings) - } \\
2.1 \text { mln parcels }\end{array}$ \\
\hline $\begin{array}{l}\text {-building real estate - associated with the right } \\
\text { of perpetual usufruct of land (long term lease) - } \\
15.6 \mathrm{mln} \text { buildings }\end{array}$ & $\begin{array}{l}\text {-building real estate - associated with the right } \\
\text { of perpetual usufruct of land (long term lease) - } \\
2.2 \mathrm{mln} \text { buildings }\end{array}$ \\
\hline $\begin{array}{c}\text {-apartment real estate (together with a share in } \\
\text { the building and in the land it is on) }-6,5 \mathrm{mln} \\
\text { flats }\end{array}$ & $\begin{array}{c}\text {-apartment real estate (together with a share in } \\
\text { the building and in the land it is on) }-2.6 \mathrm{mln} \\
\text { flats }\end{array}$ \\
\hline
\end{tabular}

Source: National Cadastral Agency of Republic of Belarus; National Statistical Committee of the Republic of Belarus. 


\section{The structure of local budget revenues and expenditures}

Real estate that is the property of a commune may be used, among other things, to: implement administrative and public service tasks, generate one-time income (in the case of sale) or periodic income (in the case of lease), or to create reserves for the purpose of future development. A commune also has an indirect impact on the owners of private real estate. It may, through a proper policy, use such real estate as an instrument to stimulate local development and influence the decisions of individuals, and as a source of income.

In Poland, according to the Act on Local Government Income, local governments may generate their own income. The sources of such income are, among other things: real estate tax, agricultural tax and forest tax, income from the commune's assets, a share in personal income tax paid by the inhabitants of a commune (39.9\%), and corporate income tax paid by businesses established in a commune (6.7\%) (Fig.1).

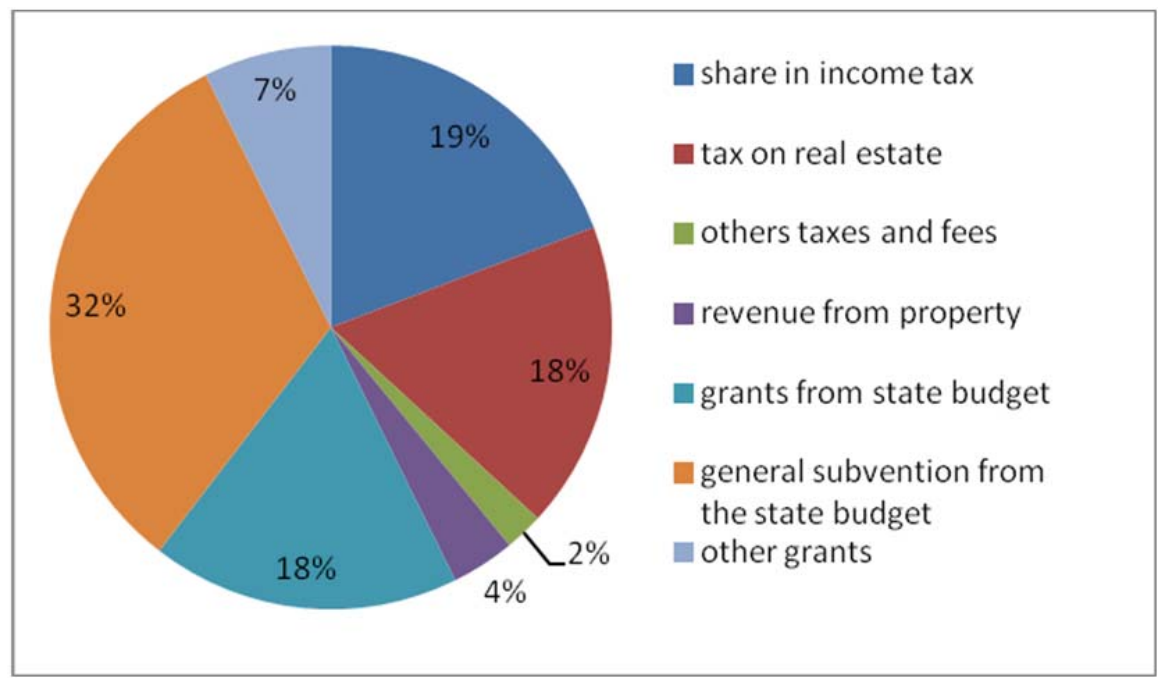

Fig. 1. The structure of local government unit budgets revenue in Poland in 2014. Source: own study based on GUS data.

In total, the three types of taxes represented approx. $18 \%$ of the entire amount of proceeds to commune budgets. This is almost equal to state subsidies and the share in income tax. Thus, they are a significant source of income (The Act of Communal Council).

In Belarus, the fraction of these taxes in GDP is relatively insignificant (about 1.2-1.3 \%). In 2015, the growth rate of land tax was $97.7 \%$ as compared with 2014 , which formed $0.4 \%$ of GDP. A drop in budget receipts is caused by a decrease in the number of entities - tax payers (by 840 units or $3.8 \%$ ).

At the same time, the fraction of real estate taxes in local budget revenues accounts for about $10 \%$ of these taxes and is the third major source of income after income tax $(27.5 \%)$ and value added tax $(16.6 \%)$. The structure of local budgets revenues in Belarus in 2015 has been presented in Fig. 2.

The reason why real estate taxes are considered to be a good source of revenue for local governments is the connection between many of the services typically funded at the local level and the benefits they bring to property values. Local income tax is recognized as a direct (e.g. an erected school) or indirect (e.g. an increase in the value of real estate as a result of the attractiveness of the location) tax advantage, because the amount of taxes paid is similar to the amount of benefits associated with services provided free of charge by local authorities to inhabitants.

In Poland, the local budget serves to pay: current expenditure, including subsidies to local establishments financed from the budget $(6 \%)$, and benefits paid to individuals free of charge and non-refundable. These benefits include grants, disability and old age pensions, and compensation. The current expenditures of establishments financed from the budget $(40 \%)$ are: salaries and related payments, and the purchase of materials and services. Another group of the expenditures of a commune are property-related expenditures: investment projects in establishments financed from the budget, acquisition of shares and contributions to commercial companies (Fig. 3).

In Belarus, according to a functional classification, the main directions of local budget expenditures are health care, public utilities and housing (Fig. 4). The structure of local budget expenditures in 2015 
was dominated by the costs associated with the current functioning of budgetary organizations, subsidized socially important services rendered to the population, and debt handling.

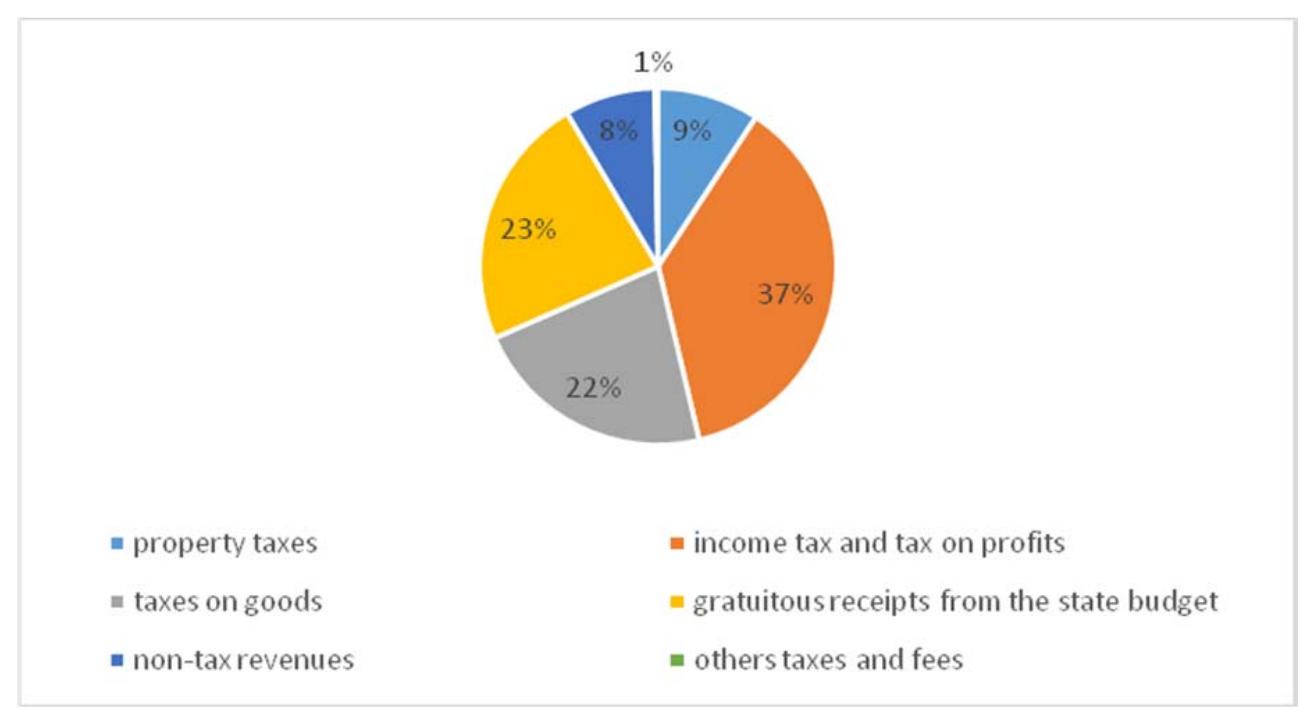

Fig. 2. Structure of local budgets revenues in Belarus in 2015. Source: own study based on data of National Statistical Committee of the Republic of Belarus.

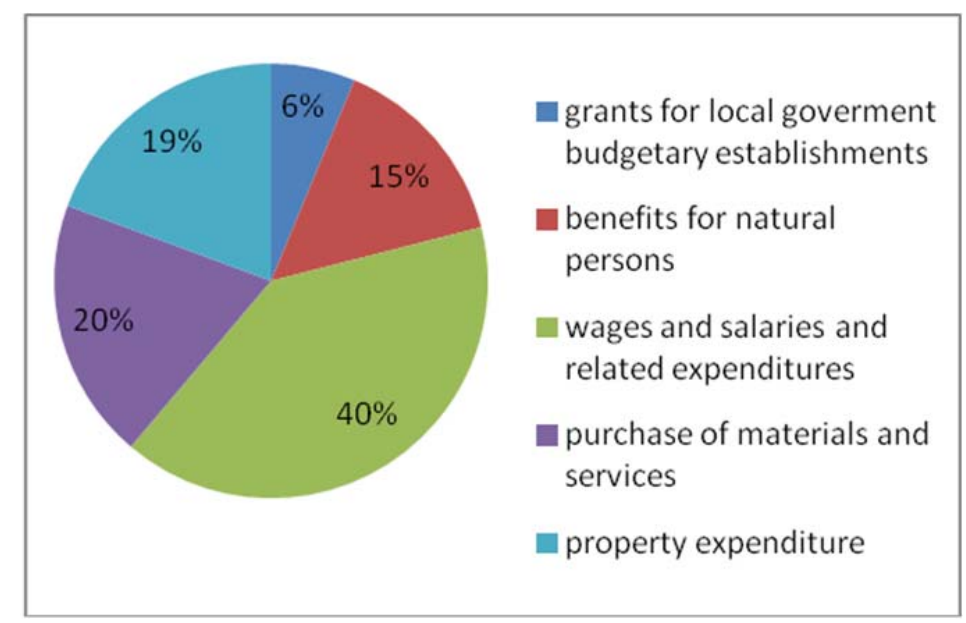

Fig. 3. Structure of local government unit (commune) budget expenditure in Poland in 2014. Source: own study based on GUS data.

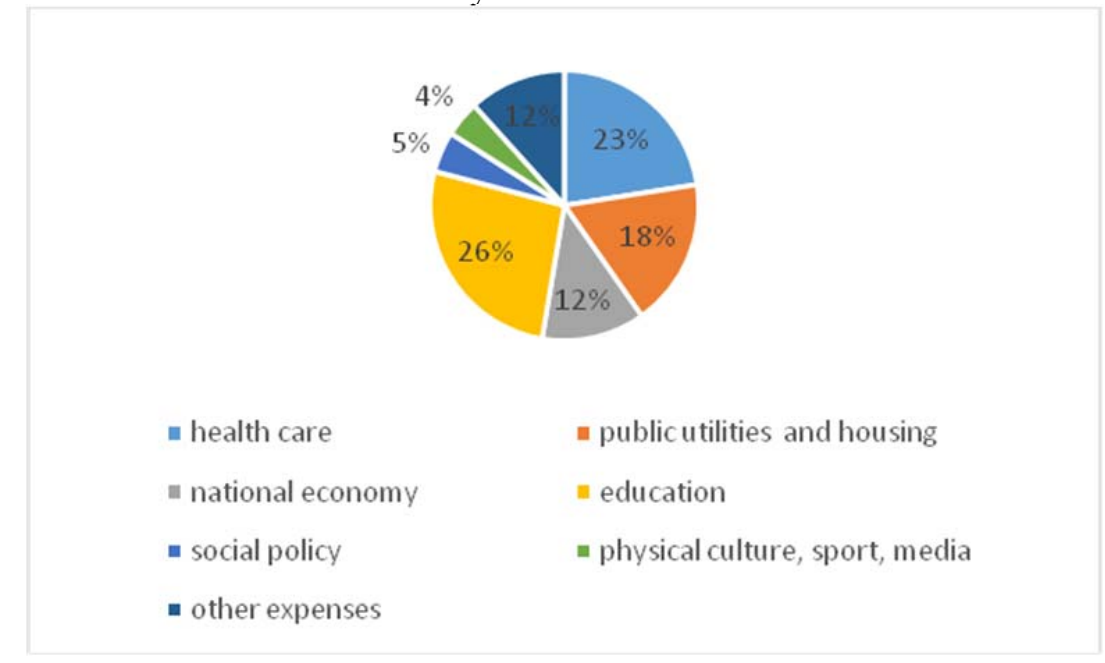

Fig. 4. Structure of local budget expenditures (a functional classification) in Belarus in 2015. Source: own study based on data of the National Statistical Committee of the Republic of Belarus. 
The structure of local budget expenditures according to an economic classification has been presented in Fig. 5.

The financing of capital expenditure was made discreetly: the share of capital expenditures decreased from $21.8 \%$ in 2014 to $16 \%$ of the total expenditure incurred by local budgets in 2015.

At the same time, the volume of funds allocated for the financing of priority expenditures (payments of wages/salaries of workers and employees, public budget transfers, payment of medicines and medical supplies, food, utilities, housing subsidies, utilities and transport services, debt service of local government and self-government) increased from $57.1 \%$ to $63.4 \%$ of the total expenditures of local budgets.
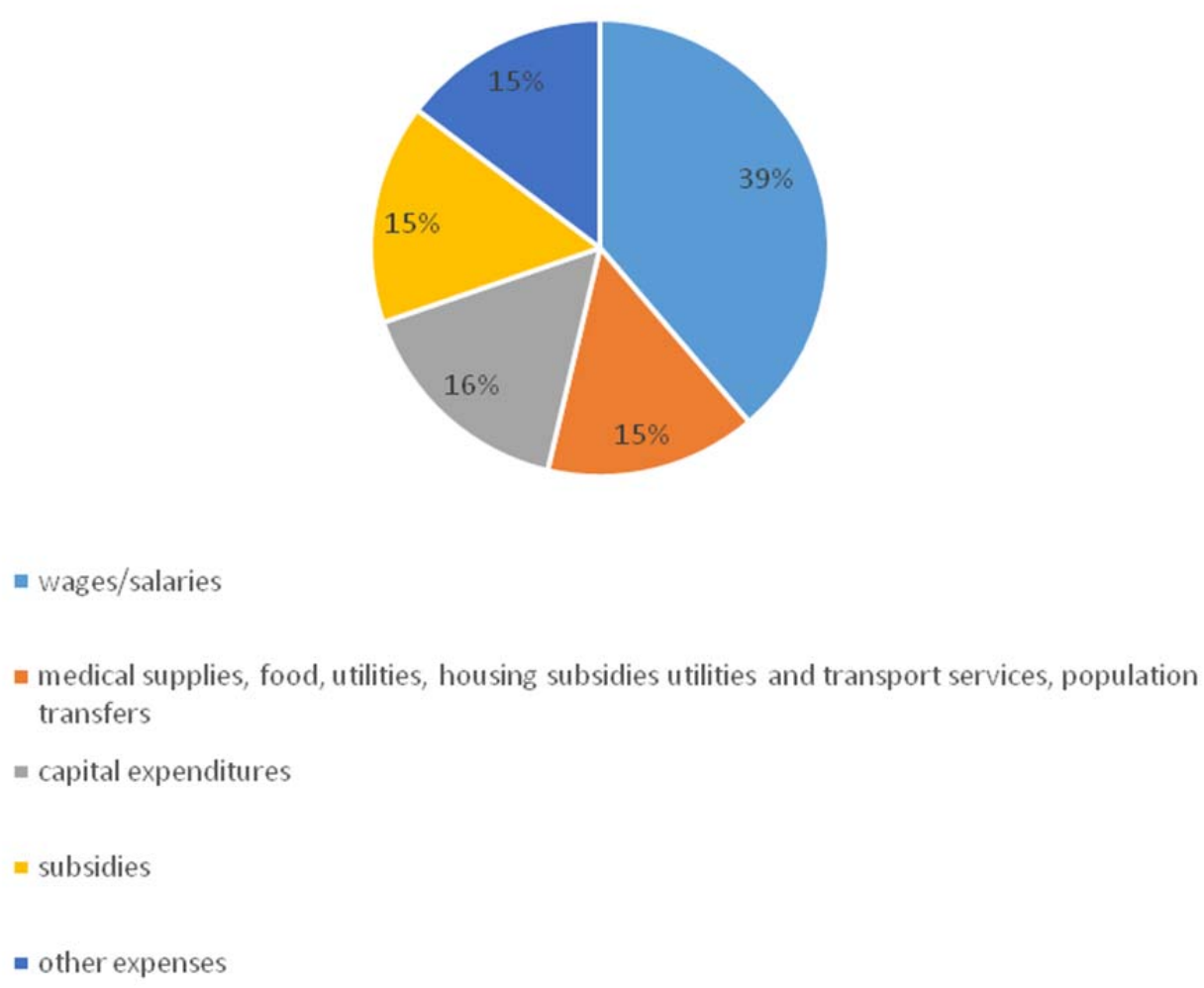

Fig. 5. Structure of local budgets expenditures (a economic classification) in Belarus in 2015. Source: own study based on data of the National Statistical Committee of the Republic of Belarus.

Taking into account the above presented description, we can conclude that local governments are considering real estate taxes, on the one hand, as a tool for promoting the effective development of real estate (land and capital structures), and on the other - as a reliable source for the formation of the local budget. Thus, regulation of tax rates makes it possible: to attract investors, and to encourage the development of infrastructure and social services in the region.

There is considerable unfulfilled potential for increasing the revenue derived from recurrent property taxes in most countries, particularly in transition countries and those with middle or low incomes (GROVER et al.2015, Taxation...2014).

\section{Analysis of real estate taxes - object and basis of taxation}

Real estate tax has certain distinguishing features that make it unique to some extent. Mainly, they are:

1) the object of tax exists regardless of the economic state and performance (so it is paid whether or not there is any income or profit),

2) real estate is firmly bound to the exact location, and thus the tax on it is paid and directed to local budgets.

The Polish real estate tax system was developed in the period of a centrally controlled economy. The legal foundation of all the fiscal obligations is based on the Constitution (Constitution...). The country's fiscal system comprises eleven tax categories, embraced by specific tax laws and regulated 
by the provisions of the Tax Ordinance. Agricultural tax, forest tax, and real estate tax are related to the ownership and use of real estate.

Taxes associated with the ownership and use of real estate in Poland have been presented in detail in Table No. 2.

Table 2

Characteristics of taxes that are related to real estate property - Poland

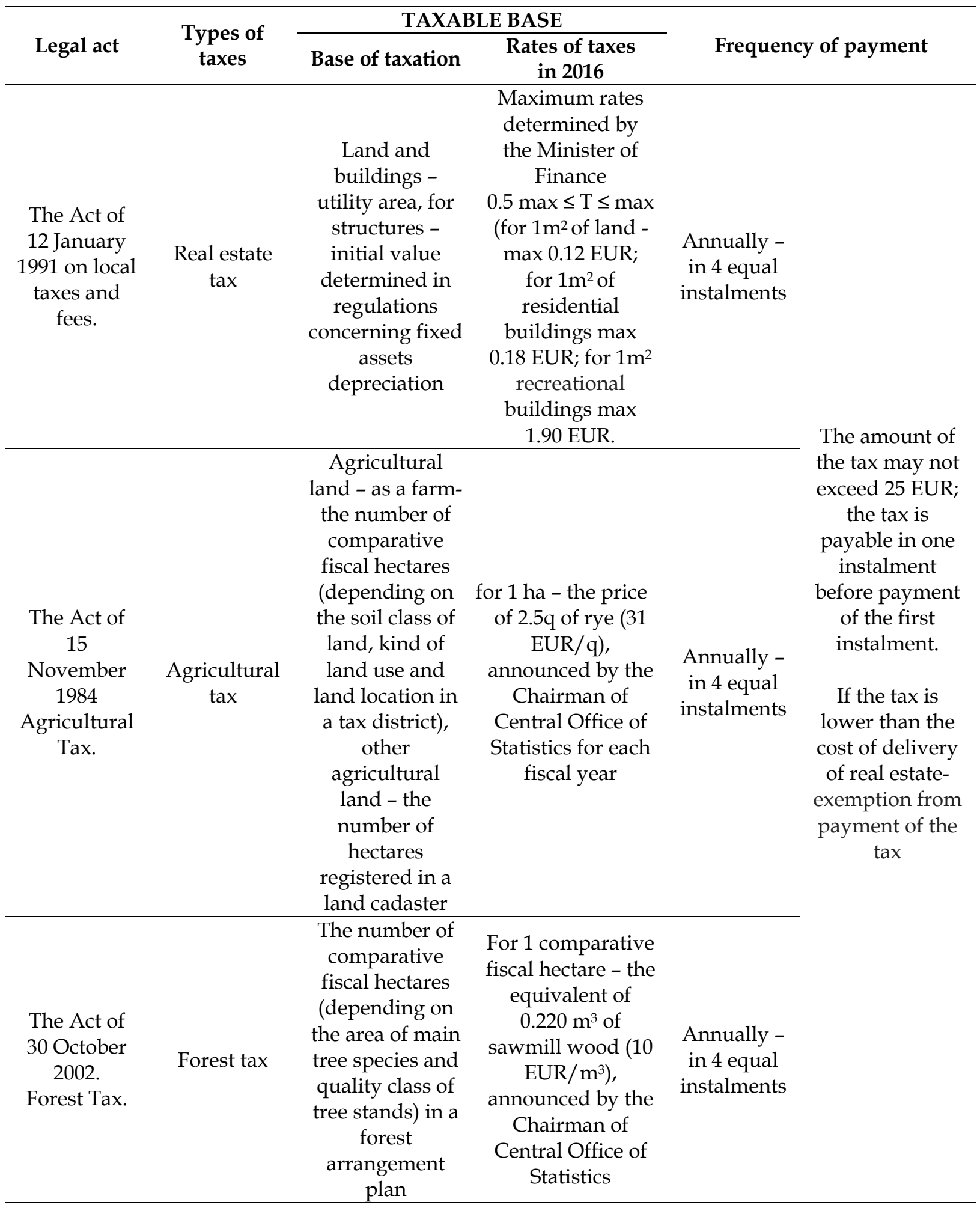

Source: prepared by the authors, based on (The Act of Tax Ordinance 1997, The Act of 21 August 1997...).

The payers of these taxes submit tax returns in which they declare the object of taxation and the 
size of the taxable area.

An audit conducted in 2012-2014 by the Polish Supreme Chamber of Control (Informacja ...), revealed discrepancies between the data concerning the size of non-residential premises in land and building registers and the data used as the basis of taxation submitted by the tax payers.

To prevent such discrepancies in the future, the Chamber's report presented post-audit recommendations for the audited local government units. These recommendations concerned, among other things:

- the maintenance of reliable real estate tax registers and keeping them up to date using available information,

- undertaking measures to ensure that tax payers submit real estate information or tax returns.

When reviewing the sources of income, communes not only increase the charges and rates of real estate taxes, but they also update data on the size of land and the usable surface of buildings.

The basic legal act related to the real estate tax in Belarus is the Tax Code (The Tax Code of ...).

The tax system of Belarus, nowadays, implies two taxes regarding property owned/used by individuals or legal entities:

- property tax (70.8\% of the total value of taxes regarding property),

- land tax (29.2\% of the total value of taxes regarding property).

The procedure for the payment of taxes is governed by Chapters 17 (Property Tax) and 18 (Land Tax) of the Tax Code. The basis of taxation is the net book value of structures (real estate tax) and the cadastral value of land (land tax). In addition to the above tax rates established by the Tax Code, local councils of deputies have the right to increase/decrease the base rate by no more than 2.5 times the amount. The resulting amount of tax is paid to local budgets. The taxes and charges related to property in Belarus have been presented in Table 3.

Table 3

Characteristics of taxes that are related to properties - Belarus

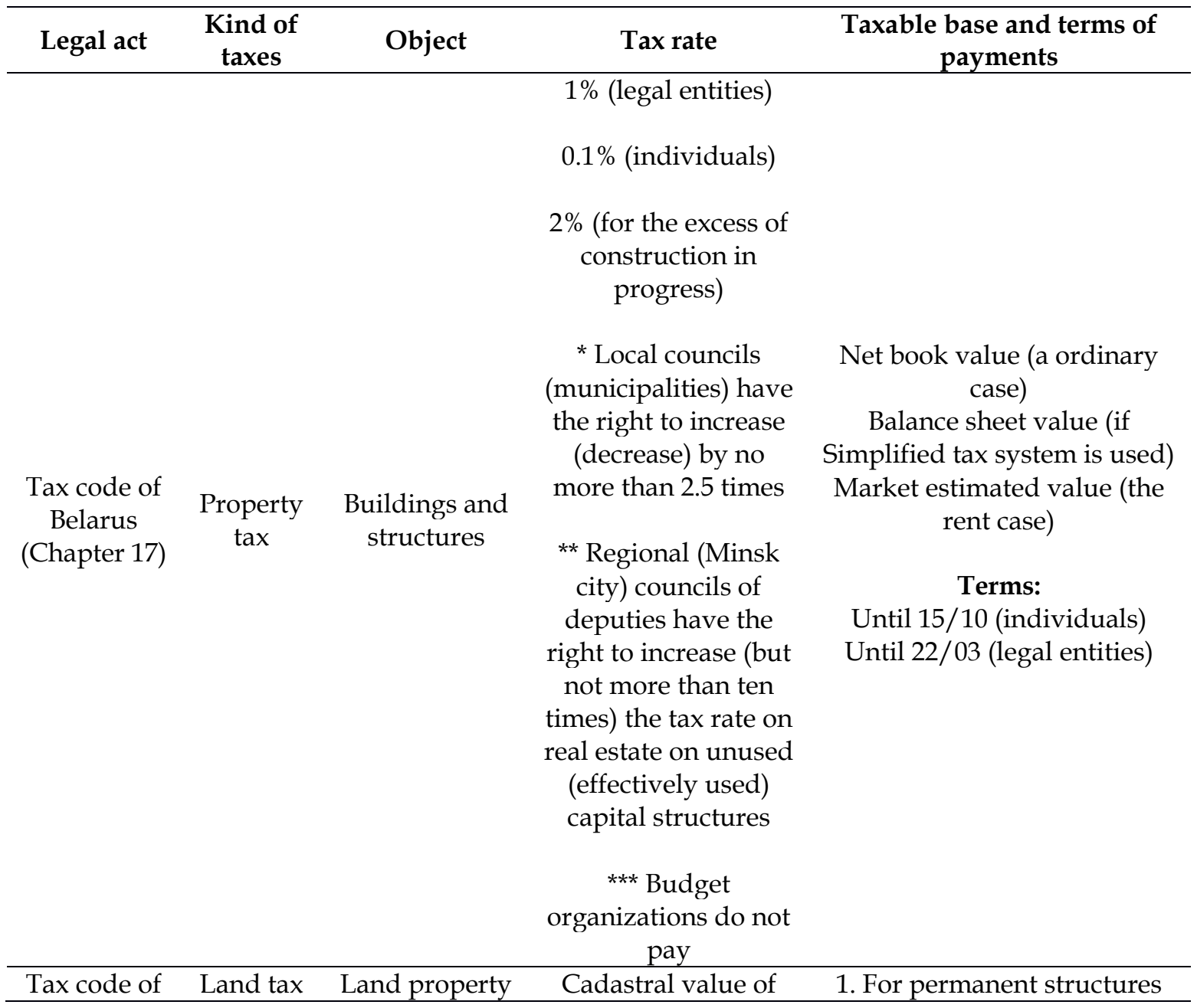




\section{Belarus (chapter 18)}

on the territory land
of the Republic
of Belarus is on
the right of
permanent or
temporary use,
lifetime
inheritable
possession or
private
property

* Exchange rate and payments are on the date 28.03.16

Source: prepared by the authors, based on the Tax Code.

The data in the table suggest that the Polish and Belarusian real estate tax systems are two different systems. Table No. 4 shows the methods of determining the amount of leisure real estate tax in similar locations in Poland and in Belarus.

Table 4

Example of the calculation of real estate tax

\begin{tabular}{|c|c|}
\hline Subject of taxation & \\
\hline $\begin{array}{l}\text { Recreational property located in a } \\
\text { rural community, about } 8 \mathrm{~km} \\
\text { away from the center of the } \\
\text { regional town. }\end{array}$ & 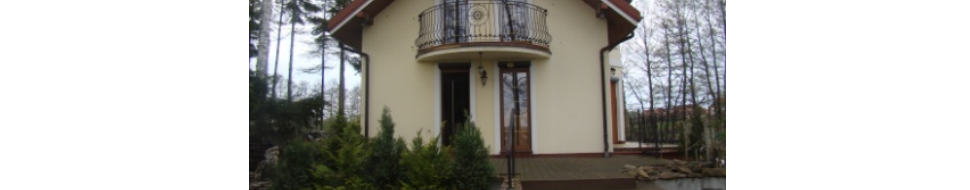 \\
\hline Description: & $\begin{array}{c}\text { Holiday house, year-round, equipped with all facilities, } 3 \\
\text { bedrooms, } 2 \text { bathrooms, office, living room, kitchen, basement } \\
\text { and terrace. }\end{array}$ \\
\hline $\begin{array}{l}\text { The plot (from land cadaster in } \\
\text { Poland): }\end{array}$ & $459 \mathrm{~m}^{2}$ \\
\hline $\begin{array}{l}\text { Usable area of the building (from } \\
\text { the taxpayer's declaration in Poland): }\end{array}$ & $83.23 \mathrm{~m}^{2}$ \\
\hline Built & 2015 \\
\hline $\begin{array}{l}\text { Market value of recreational real } \\
\text { estate (plot }+ \text { building) }\end{array}$ & $\begin{array}{c}94,000 \text { euro } \\
\text { of which } 11,000 \text { euro for the plot - }\end{array}$ \\
\hline
\end{tabular}




\begin{tabular}{|c|c|c|c|c|c|}
\hline \multicolumn{6}{|c|}{ Annual real estate tax (in Euro) } \\
\hline & POLAND & \multicolumn{2}{|c|}{ BELARUS } & \multicolumn{2}{|c|}{ BELARUS } \\
\hline & - & \multicolumn{2}{|c|}{$\begin{array}{l}\text { if the cadastral value of the plot } \\
\qquad<6,400 \text { euro }\end{array}$} & \multicolumn{2}{|c|}{$\begin{array}{l}\text { if the cadastral value of the plot } \\
\qquad>6,400 \text { euro }\end{array}$} \\
\hline & - & Individuals & $\begin{array}{c}\text { Legal entities } \\
\text { (businesses) }\end{array}$ & Individuals & $\begin{array}{l}\text { Legal entities } \\
\text { (businesses) }\end{array}$ \\
\hline Land & $\begin{array}{c}459 \mathrm{~m}^{2} \times 0.10 \\
\text { EUR } \\
=45 \mathrm{EUR}\end{array}$ & $\begin{array}{c}0.0459 \text { ha } \times 4 \\
\text { EUR }=\mathbf{0 . 1 8} \\
\text { EUR }\end{array}$ & $\begin{array}{c}0.0459 \text { ha } x \\
61 \mathrm{EUR}=\mathbf{2 . 8} \text { EUR }\end{array}$ & $\begin{array}{l}11,000 * 0.001= \\
11 \text { EUR }\end{array}$ & $\begin{array}{c}11,000^{*} 0.01= \\
110 \text { EUR }\end{array}$ \\
\hline Building & $\begin{array}{c}83.23 \mathrm{~m}^{2} \times 1.80 \\
\text { EUR } \\
=\mathbf{1 5 0 E U R}\end{array}$ & $\begin{array}{c}83,000 \times 0.001= \\
\text { 83EUR }\end{array}$ & $\begin{array}{l}83,000 \times 0.01= \\
\text { 830EUR }\end{array}$ & $\begin{array}{l}83,000 \times 0.001= \\
\text { 83EUR }\end{array}$ & $\begin{array}{l}83,000 \times 0.01= \\
\text { 830EUR }\end{array}$ \\
\hline
\end{tabular}

Source: own study.

We have to stress that, in Belarus, the cadastral value of a similar plot is usually much less than 6,400 euro. Thus, the land tax per ha is accounted as 4 euro per ha for individuals and 61 euro for businesses. If the cadastral value of a plot is more than 6,400 euro, individuals pay taxes at the rate of $0.1 \%$, while legal entities at the rate of $1 \%$ of the cadastral value. The basis of taxation for buildings is the net book value, which, in this case, is the same as the market value.

\section{The basis of taxation: the value or the size of real estate?}

The two types of taxation bases - the size and the value of real estate, respectively - were analyzed in regards to the strengths and weaknesses of the two systems.

Table 5

Size as the basis of taxation

\begin{tabular}{|c|c|}
\hline Strengths & Weaknesses \\
\hline $\begin{array}{l}\text { It is possible to determine the size of every } \\
\text { object of taxation }\end{array}$ & $\begin{array}{c}\text { It is necessary to verify the size of premises and } \\
\text { buildings declared by a tax payer directly on } \\
\text { the site, due to incomplete registers of } \\
\text { buildings and premises }\end{array}$ \\
\hline $\begin{array}{l}\text { When it is necessary to increase the amount of } \\
\text { tax, the basis of taxation does not need to be } \\
\text { changed, which means that there are no extra } \\
\text { costs associated with the revaluation of real } \\
\text { estate }\end{array}$ & $\begin{array}{c}\text { An increase in the tax rate must be justified } \\
\text { when it is necessary to increase proceeds to the } \\
\text { local budget }\end{array}$ \\
\hline $\begin{array}{c}\text { It is possible to accurately forecast new } \\
\text { building spaces to be put into operation, and } \\
\text { thus, the amount of proceeds to the commune } \\
\text { budget }\end{array}$ & $\begin{array}{l}\text { Causes a feeling of unfair treatment among tax } \\
\text { payers if worse real estate is charged the same } \\
\qquad \text { tax }\end{array}$ \\
\hline $\begin{array}{l}\text { Does not discourage the construction of high- } \\
\text { standard buildings }\end{array}$ & $\begin{array}{l}\text { Is a poor encouragement for owners to make } \\
\text { the best use of real estate and prevent the } \\
\text { inefficient use of expensive locations }\end{array}$ \\
\hline $\begin{array}{l}\text { Does not force less wealthy persons to move } \\
\text { to cheaper locations }\end{array}$ & $\begin{array}{l}\text { Does not capture the re-zoning fee (this } \\
\text { function is attempted to be performed by re- } \\
\text { zoning charges) }\end{array}$ \\
\hline $\begin{array}{l}\text { The tax is not directly affected by crises in the } \\
\text { real estate market }\end{array}$ & $\begin{array}{l}\text { Does not provide for the commune's } \\
\text { expenditure on technical infrastructure (this is } \\
\text { done by betterment levies). This results in the } \\
\text { need to undertake prolonged and costly } \\
\text { administrative procedures, because owners } \\
\text { appeal against the value determined for these } \\
\text { purposes }\end{array}$ \\
\hline
\end{tabular}

Source: own elaboration 
Value as the basis of taxation

\begin{tabular}{|c|c|}
\hline Strengths & Weaknesses \\
\hline Gives a sense of fair determination of taxes & $\begin{array}{c}\text { Generates the need to have well-organized and } \\
\text { costly databases of real estate properties and } \\
\text { their prices. }\end{array}$ \\
\hline $\begin{array}{c}\text { Motivates the owners and users of real estate } \\
\text { to make the best use of the potential of real } \\
\text { estate }\end{array}$ & $\begin{array}{l}\text { Involves the risk of overestimating or } \\
\text { underestimating the value }\end{array}$ \\
\hline $\begin{array}{l}\text { Increasing the tax does not require additional } \\
\text { justification when the value of real estate } \\
\text { increases, which translates into relatively high } \\
\text { rates of collectability }\end{array}$ & $\begin{array}{l}\text { Often causes prolonged and costly appeal } \\
\text { procedures in the process of valuation }\end{array}$ \\
\hline $\begin{array}{l}\text { There is a close link between many services } \\
\text { usually financed at the local level and the } \\
\text { value of real estate }\end{array}$ & $\begin{array}{l}\text { Requires a clear reason of the object of taxation: } \\
\text { whether it is land and structures or only a plot } \\
\text { of land }\end{array}$ \\
\hline \multirow[t]{4}{*}{$\begin{array}{l}\text { Prevents false tax returns if taxes and other } \\
\text { fees are charged on value }\end{array}$} & $\begin{array}{l}\text { Lack of convincing arguments as to the use of } \\
\text { real estate for tax purposes: actual or optimal }\end{array}$ \\
\hline & $\begin{array}{l}\text { Causes "forced" sale and irregularities in the } \\
\text { real estate market, and may lead to unexpected } \\
\text { social and economic consequences }\end{array}$ \\
\hline & $\begin{array}{l}\text { Causes a sense of unfair treatment among tax } \\
\text { payers if communes where real estate has } \\
\text { lower value are forced to determine higher tax } \\
\text { rates in order to satisfy the same needs of their } \\
\text { inhabitants as communes with more expensive } \\
\text { real estate }\end{array}$ \\
\hline & $\begin{array}{l}\text { Causes ambiguity of requests for tax payment } \\
\text { in the case of different tax rates with respect to } \\
\text { the respective elements of real estate that have } \\
\text { different values }\end{array}$ \\
\hline
\end{tabular}

Source: own elaboration.

\section{Conclusions}

Because of the nature of real estate, it is possible to choose either physical or economic parameters as the basis of taxation, which makes it difficult to determine uniform and unequivocal taxation.

In general, the collectability of real estate taxes is high. However, most tax arrears are caused by the fact that there is no relationship between the amount of tax and the inability to pay tax among families with low social status or senior citizens.

Unpaid taxes reduce the ability to implement projects for the benefit of a commune's inhabitants and are perceived as unjust by those who do pay taxes.

Based on the real estate tax system in Belarus, we can distinguish the following major problems that hinder development:

- unclear mechanisms of encouraging the efficient use of property,

- the lack of a unified cadaster of land plots and structures,

- the absence of land ownership,

- the lack of fair criteria for the effective and efficient use of real estate.

A discussion has been going on in Poland for some time now about the necessity to reform the real estate tax system and introduce ad valorem tax, although to no avail as yet. The main reason is that tax 
payers are afraid that taxes might go up significantly, which means that there is no social approval of, or political will to undertake the reform. Also, there is no agreement as to the principles of real estate valuation or as to what kind of real estate use should be considered in the valuation.

Accordingly, the reform of every tax system should be actively participated in by tax payers during every stage of the procedure, and should be preceded by a broad information campaign to make tax payers aware of the costs and benefits of the new system.

In order to improve the real estate tax system, it is necessary to perform the following procedure:

Create an efficient tax administration $\rightarrow$ register all objects of taxation in a real estate cadaster $\rightarrow$ create an up-to-date database of real estate prices and properties $\rightarrow$ undertake a transparent base and method of valuation $\rightarrow$ determine the base tax rate and the factor of its increase or decrease $\rightarrow$ collect and use taxes in line with the principles of local development.

To sum up, it should be noted that the taxation of real estate involves many decisions that affect real estate management and land use and, consequently, the economic conditions of real estate owners and the entire community of a given area. Such decisions should not only be accepted by political and administrative bodies, but they should also take into account important economic and social aspects.

\section{References}

Almy R., 2001, A Survey of Property Tax. Systems in Europe, p.125, http:/ / www.agjd.com/ EuropeanPropertyTaxSystems.pdf.

BARAŃSKA A., 2013, Real Estate Mass Appraisal in Selected Countries - Functioning Systems and Proposed Solutions, Real Estate Management and Valuation, Volume 21, Issue 3, Pages 35-42, ISSN (Online) 1733-2478, DOI: 10.2478/ remav-2013-0024.

BIRD R. M., SLACK E., 2002, Land and Property Taxation http:/ /www1.worldbank.org/publicsector/ decentralization/June2003Seminar/LandPropertyTaxation.pdf

BuRnS T., DARLYMPLE K., 2008, Conceptual Framework for Governance in Land Administration, International Federation of Surveyors, August 2008, Paper has been prepared for and presented at the FIG Working Week in Stockholm, Sweden 14-19 June 2008.

Constitution of the Republic of Poland of 2 April 1997, Journal of Laws, 1997, No. 78, item 483.

Dale P.F., MCLaughlin J.D., 1999, Land Administration, Oxford University Press, pp. 169, ISBN: 0198233906.

FLIS P., 2015, Podatki od nieruchomości a praktyka podatkowa gmin w Polsce, p. 230, Oficyna wydawnicza SGH, ISBN 978-83-8030-029-3 [Property taxes and tax practice of municipalities in Poland].

GŁUSZAK M., MARONA B., 2015, Podatek katastralny. Ekonomiczne uwarunkowania reformy opodatkowania nieruchomości (Cadastral tax. Economic Conditions of the Reform of Property Taxation) (in Polish), Poltex pp. 256.

Grover R., TÖRHÖNEn M.P., Munro-FAure P., ANAND A., 2015, Property Valuation and Taxation for Fiscal Sustainability and Improved Local Governance: Case Studies from the ECA Region, In: Land Tenure Journal, ed. FAO and The World Bank, pp. 7-28, ISSN 2079-715X.

HunKer K., QUINTERO J., GINN V., 2015, The Freedom to Own Property. Reforming Texas Local Property Tax, Texas Public Policy Foundation, pp. 12.

Informacja o wynikach kontroli Prawidłowości i skuteczność realizacji przez jednostki samorządu terytorialnego podatków lokalnych oraz dochodów majątku (Information on the Results of the Audit Regularity and Effectiveness of the Implementation by Local Government Units and Local Tax Income Assets) (in Polish) (KAP-4101-004-00/2014 nr ewid. 206/2014/P/14/005/KAP).

Najwyższa Izba Kontroli, Departament Administracji Publicznej

(file:/ / C:/Users/Elżbieta\%20Zysk/Downloads/Raport\%20NIK\%20podatkilokalne\%20Copy.pdf).

Institute on Taxation and Economic Policy, 2011, Policy Brief - How Property Taxes Work, pp. 2.

KОКОт S., 2009, System opodatkowania nieruchomości w Polsce jako element gospodarki nieruchomościami gminy- specyfika istotnych problemów (Problems of Taxation of Real-Estate in Context of the Communal Real-Estate Economy) (in Polish), Acta Sci.Pol. Administratio Locorum, No. 8 (1),

Ross J. M., 2014, A Primer on State and Local Tax Policy: Trade-Offs among Tax Instruments, Mercatus Research, George Mason University, p.39.

SADOWSKA-SPYCHAŁA J., 2013, Rola samorządu gminnego w rozwoju przedsiębiorczości wiejskiej (The Role of Local Government in the Development of Rural Entrepreneurship) (in Polish), Zeszyty Naukowe Polityki Poznańskiej, Nr 61, Organizacja i Zarządzanie. 
ŠUBIC KOVAČ M., 2015, New Real Estate Taxes in Slovenia, in: Hepperle, Ervin (ed.) Challenges for Governance Structures in Urban and Regional Development: Zürich: VDF Fochschulverlag AG an der ETH, pp. 177-194.

Taxation trends in the European Union Data for the EU Member States, Iceland and Norway, Edition 2014, http://ec.europa.eu/eurostat/documents/3217494/5786841/KS-DU-14-001-EN.PDF/7bec4a16f111-4386-a4b4-8f1087be1063?version=1.0.

The Tax Code of the Republic of Belarus -The Special Part, Law No. 71-3 of December 29, 2009.

TROJANEK M., 2015, Gospodarowanie nieruchomościami w gminach w aspekcie ich dochodowości (Management of real estate in the municipalities in terms of their profitability) (in Polish), Uniwersytet Ekonomiczny $\mathrm{w}$ Poznaniu, p. 218,

The Act of Tax Ordinance (Ustawa Ordynacja podatkowa), Journal of Laws, 1997, No 137, item. 926.

The Act of 21 August 1997 About the Real Estate Management [Ustawa z dnia 21 sierpnia 1997 r. o gospodarce nieruchomościami], Journal of Laws, 2004, No. 206, item. 2109.

The Act of 23 April 1964 - Civil Code (Ustawa z dnia 23 kwietnia 1964 r. - Kodeks cywilny), Journal of Laws $16 / 64$, item.93 with amendments.

The Act of 12 January 1991 on local taxes and fees (Ustawa o podatkach $i$ optatach lokalnych), Journal of Laws, 2015, No. 528, 699, 774, 1045, 1283, 1777, 1890.

The Act of 30 October 2002 Forest Tax (Ustawa o podatku leśnym), Journal of Laws, 2015, item 1045.

The Act of 15 November 1984 Agricultural Tax (Ustawa o podatku rolnym), Journal of Laws, 2015, item. 1045.

The Act of Communal Council (Ustawa o samorzadzie gminnym), Journal of Laws, 2001, No. 142, item. 1591.

WALACIK M., 2015. Property taxation in Poland. In: Land Tenure Journal. Ed. FAO and The World Bank. pp. 101-118. ISSN 2079-715X

YOUNGMAN J., RESCHOWSKY A., 2007. The strengths of the property tax. The Boston Globe 